\title{
IMPLEMENTASI PEMBINAAN TOLERANSI BERAGAMA MELALUI METODE SCRIPTURAL REASONING PADA KOMUNITAS YOUNG INTERFAITH PEACEMAKER COMMUNITY
}

\author{
Mochammad Jiva Agung Wicaksono \\ Universitas Islam Negeri Sunan Gunung Djati, Bandung \\ *E-mail:jiva.uinsgd@gmail.com
}

\begin{abstract}
This article examines the role of Young Interfaith Peacemaker Community (YIPC) in spreading peace values. This community provides a safe and neutral place to its members and the general public to create peace. On way in fostering religious tolerance is to engage in interfaith dialogue through the method of Scriptural Reasoning. This research aims to develop religious tolerance through mutually reading and studying the scriptures together in YIPC. This study uses a qualitative approacch with additional descriptive methods. The data collection was done through interviews, participant observation, and documentation study. The research shows that fostering religious tolerance through the method of Scriptural Reasoning in Young Interfaith Peacemaker Community has been fairly succesful. The impact of the activity is quite strong. The implementation process runs in accordance with the general goal and the outcomes truly impact its members. This is proved by the change in attitude and personal statements of the members.
\end{abstract}

Keyword : Religious Tolerance, Scriptural Reasoning, Young Interfaith Peacemaker Community

Abstrak. Artikel ini membahas peran Komunitas Young Interfaith Peacemaker Community (YIPC) dalam menyebarkan nilai-nilai kedamaian. Komunitas ini memberikan ruang yang luas kepada anggotanya dan kepada masyarakat umum untuk dapat menjadi para penyebar perdamaian. Salah satu pembinaan toleransi beragama yang dilakuannya ialah dengan melakukan dialog lintas iman melalui metode Scriptural Reasoning (SR). Penelitian ini bertujuan untuk mengetahui implementasi pembinaan toleransi beragama melalui metode SR pada komunitas YIPC. Penelitian ini menggunakan pendekatan kualitatif dengan metode deskriptif. Pengumpulan data dilakuan melalui wawancara, observasi partisipatif, dan studi dokumentasi. Hasil penelitian menunjukkan bahwa pembinaan toleransi beragama melalui metode SR pada komunitas YIPC telah berjalan cukup baik. Hal ini dapat dibuktikan dengan adanya perencanaan yang cukup matang. Proses pelaksanaan pun berjalan secara umum berjalan sesuai dengan perencanaan, dan hasil pembinaan ini sudab banyak dirasakan oleh para anggotanya. Hal ini dapat dibuktikan dengan perubahan sikap dan pernyataan pribadi para anggota.

Kata kunci: Toleransi Beragama, Scriptural Reasoning, Young Interfaith Peacemaker Community. 


\section{PENDAHULUAN}

Sejatinya Tuhan menurunkan agama agar manusia dapat hidup dengan penuh kedamaian, cinta, dan kasih. Jika masih ada di antara mereka yang membuat keributan, penindasan, ketakutan, dan kekacauan sudah dipastikan bahwa dia belum menghayati ajaran agama tersebut dengan benar.

Sayangnya kerukunan umat beragama di Indonesia saat ini sedang diuji dari berbagai arah. Konflikkonflik yang sedang terjadi di luar negeri masuk dan menyebar ke Indonesia, selain itu masuk pula pemikiran-pemikiran yang tidak sesuai dengan norma bangsa kita. Hal ini diperparah dengan kehadiran beberapa oknum yang melakukan tindakan kekerasan dengan dalih agama, padahal kasus tersebut hanyalah bermuatan politik, ekonomi, dan sebagainya sehingga akhirnya terjadilah keretakan hubungan antar umat beragama di Indonesia.

Seperti yang dicatat oleh Bernas Jogja dari data The Wahid Institute menunjukkan sejak Januari hingga November 2008, di Indonesia terjadi 232 kasus yang melibatkan agama. Kasus-kasus tersebut dibagi ke dalam delapan kategori, yaitu penyesatan, kekerasan berbasis agama, regulasi bernuansa agama, konflik tempat ibadah, kebebasan berpikir dan berekspresi, hubungan antar umat beragama, fatwa keagamaan, dan isuisu moralitas serta pornografi. Kekerasan berbasis agama menjadi kasus terbanyak, yaitu 55 kasus (Su'aidi, 2012, hal. 309). Bahkan, masih dari hasil laporan The Wahid Institute, tindakan tersebut terus meningkat hingga pada akhir tahun 2010 dengan jumlah pelanggaran sebesar 64 kasus atau rata-rata 5 kasus per bulan (Tontowi dkk. 2010, hal. 5).

Kasus intoleransi juga menjalar di dunia pendidikan. Survei nasional ini dilakukan oleh Tim PPIM UIN Jakarta di tahun 2017 terhadap guru dan dosen PAI, juga siswa dan mahasiswa yang tersebar di 34 provinsi. Ditemukan bahwa hanya ada 55.51\% siswa dan mahasiswa yang menyetujui adanya pendirian rumah ibadah agama lain di lingkungan tempat tinggal mereka. $53.74 \%$ dari mereka setuju bahwa Yahudi adalah musuh Islam (PPIM, 2017).

Data terbaru, seperti yang dirilis oleh Lembaga Survei Indonesia (LSI) pada tahun 2019 terungkap bahwa lebih dari 50\% masyarakat Muslim keberatan jika ada non Muslim yang menjadi pejabat negara, seperti presiden $(59.1 \%)$, wakil presiden (56.1\%), gubernur (52\%), bupati/walikota (51.6\%). Selain itu sekitar 53\% Muslim keberatan jika ada non Muslim mendirikan tempat ibadah di tempat tinggalnya. Juga ada 36.4\% Muslim yang keberatan jika ada non Muslim yang mengadakan acara keagamaan di sekitar rumahnya (LSI, 2019).

Tentu saja hasil survei di atas sungguh mengkhawatirkan masa depan kerukunan umat beragama. Untuk itu diperlukan sebuah upaya pencegahan yang salah satunya ialah berupa kegiatan diskusi lintas iman di mana setiap pemeluk agama dapat saling mengutarakan dan atau bertanya 
mengenai ajaran agama teman diskusinya tanpa harus memaksa mereka untuk menyetujuinya. Dari sini akan memunculkan berbagai macam efek positif, salah satunya yaitu tumbuhnya sikap toleran kepada umat yang berbeda agama.

YIPC adalah sebuah komunitas lintas iman non pemerintah yang memiliki tujuan untuk menyebarkan perdamaian antar umat beragama. Salah satu upaya yang dilakukan oleh komunitas ini adalah dengan melakukan sebuah dialog lintas agama dengan berfokus kepada ajaran kitabkitab suci yang mereka yakini. Metode dialog ini dinamakan Scriptural Reasoning (SR). Sebuah metode dialog lintas iman yang ditemukan dan dikembangkan oleh Peter Ochs (2012, 16-22) ini dapat berjalan dengan membuat sebuah kelompok kecil yang terdiri dari minimal dua pemeluk agama yang berbeda, lalu mereka membahas dan mencoba untuk menalar serta menafsirkan kitab-kitab suci (Taurat, Injil, Zabur, Alquran) tersebut sesuai dengan tema pembahasan yang telah disepakati.

\section{METODE PENELITIAN}

Dikarenakan peneliti ingin
menemukan pemahaman dan
penafsiran yang mendalam terhadap
suatu kenyataan dan atau fakta yang
relevan, maka peneliti menggunakan
pendekatan kualitatif dengan tiga
teknik pengumpulan data, yakni
pertama observasi peran serta di mana
peneliti ikut bergabung melakukan
aktivitas dialog SR bersama peserta
dialog lain di regional Yogyakarta dan
Bandung. Tidak hanya itu, peneliti juga

melakukan wawancara terpimpin di mana pertanyaan yang akan diajukan sudah dipersiapkan terlebih dahulu dengan menggunakan pedoman wawancara yang berisikan pertanyaanpertanyaan seputar perencanaan, pelaksanaan, dan evaluasi model dialog SR. Selain itu, wawancara ini bersifat terbuka, dalam arti narasumber dapat menjawab secara bebas tidak terikat oleh pertanyaan yang telah ditentukan sebelumnya. Untuk menguatkan informai yang didapat, peneliti pun menggunakan semacam alat bantu ketika melakukan wawancara, seperti alat perekam, gambar, atau material lainnya. Beberapa narasumber yang diwawancara seperti pendiri komunitas, peserta kegiatan SR, dan anggota YIPC. Di sisi lain peneliti juga melakukan studi dokumentasi dengan mengumpulkan beberapa dokumen yang relevan seperti buku panduan YIPC, draf materi SR, tulisan dari media sosial Facebook YIPC dan dari website resminya. Tak lupa penulis pun melakukan upaya pengecekan data (member check). Setelah terkumpul data dianalisis melalui tiga tahapan yakni reduksi data, paparan data, dan penyimpulan yang dilakukan secara berulang dan dengan proses triangulasi sembari dibandingkan dengan teoriteori pembinaan yang relevan sehingga diperoleh pemahaman dan kesimpulan yang akurat.

\section{HASIL PENELITIAN DAN PEMBAHASAN}

\section{Profil Singkat Young Interfaith Peacemaker Community}


Terbentuknya YIPC berawal dari 2 orang mahasiswa ICRS (Andreas Jonathan dan Ayi Yunus Rusyana) yang mengadakan Young Peacemaker Training di Gedung Pasca Sarjana UGM Yogyakarta pada 9-12 Juli 2012. Training ini diikuti oleh 25 orang mahasiswa S1 Muslim dan Kristiani dari berbagai kampus di Yogyakarta dan menjadi cikal bakal lahirnya Young Peacemaker Community (YPC) Jogjakarta. Dalam training ini dipelajari 12 Nilai Perdamaian dari Peace Generation. Sebagai tindak lanjut dari training itu, mulai bulan September 2013 diadakan pertemuan regular dari para anggota YPCJ dengan mengadakan interfaith dialogue, kajian kitab suci, serta mempersiapkan Student Interfaith Peace Camp pada November 2012. Peace Camp yang pertama ini diadakan di Pakem dan diikuti sekitar 30 orang mahasiswa baik dari Jogjakarta maupun luar Jogjakarta dengan mengambil tema "Building Peace Generation Through Young Peacemakers". Tema ini kemudian menjadi motto atau pernyataan misi YPCI.

Semakin beragamnya asal daerah peserta, maka setelah Peace Camp, nama YPC Jogja diubah menjadi YPC Indonesia (YPCI). Di tahun 2013 antara bulan Maret sampai Mei, YPCI mengadakan Student Interfaith Peace Camp di Medan (untuk Sumatera), di Trawas (untuk Jawa Timur), dan di Kaliurang (untuk Jogjakarta dan Jawa Tengah). Rata-rata jumlah peserta Peace Camp adalah 30 orang mahasiswa Muslim dan Kristiani. Sejak itu, YPCI telah eksis di 3 kota, yaitu Jogjakarta, Medan, dan Surabaya, dengan mengadakan regular dialog setiap minggunya.
Di bulan Juli 2013, saat memperingati 1 tahun usia YPCI, diadakanlah Young Interfaith Peacemaker National Conference yang diikuti hampir 50 orang dari berbagai kota di Indonesia. Conference yang diadakan di Magelang ini mengambil tema 'Loving God-Loving Others, Let's Do Something About It dengan mengambil landasan diskusi berdasar dokumen ' $A$ Common Word Between You and Us'. Di akhir National Conference inilah, nama YPCI disempurnakan menjadi Young Interfaith Peacemaker Community (YIPC) Indonesia dengan tiga cabang, yaitu YIPC Medan, YIPC Joglosemar dan YIPC Jawa Timur.

YIPC memiliki dua unsur utama dalam kegiatannya, yaitu interfaith dialogue dan pendidikan perdamaian. Untuk interfaith dialogue, YIPC menggunakan metode Scriptural Reasoning sebagaimana yang dikembangkan oleh Peter Ochs. Adapun mengenai pendidikan perdamaian, ada beberapa kegiatan yang dilakukan seperti Student Interfaith Peace Camp, National Conference, dan sebagainya.

\section{Scriptural Reasoning(SR)}

SR adalah latihan membaca kitab suci sendiri dan kepercayaan lain (interfaith) yang dilakukan oleh beberapa pemeluk agama Abrahamik seperti Islam, Kristen, dan Yahudi yang berkumpul bersama untuk membaca pasal pendek dari kitab suci mereka (Kepnes, 2006, hal. 367; Ochs, 2012, hal. 17; Geddes, 2004, hal. 93).

SR bukanlah sebuah konsensus karena pesertanya tidak harus setuju satu sama lain. Mereka mungkin tidak menerima teks yang lain sebagai kitab 
suci atau sebaliknya setuju dengan yang lain. SR akan selalu dapat berjalan bahkan ketika para peserta sangat berbeda, dan perbedaan itu sangat berarti bagi mereka untuk dapat memahami perbedaan satu sama lain (Harrison, 2010, hal. 1; Geddes, 2004, hal. 93, Kepnes, 2006, hal. 367-368).

SR berguna untuk memperdalam pemahaman. Peserta SR akan belajar banyak tentang kitab suci sendiri dan kitab agama lain, dan bagaimana caranya dibaca. Kebanyakan peserta akan merasa senang saat peserta lain yang berbeda keyakinan dengannya sedang membaca kitab sucinya. Mereka juga akan memperoleh pengalaman dan ilmu baru karena berusaha membaca teks di tengahtengah orang yang mungkin belum pernah membacanya. Mereka juga mungkin akan melihat atau memahami kitab sucinya melalui mata atau cara pandang peserta lain (Kepnes, 2006, hal. 369).

Selain itu SR dapat memperdalam hubungan. Peserta akan menghabiskan waktu dengan orangorang dari agama yang berbeda, dan membicarakan teks kitab suci yang mereka pedulikan (teks yag menjadi pusat hidup mereka). Peserta juga akan membagikan teks yang sangat berarti untuk anggota yang lain. Peserta juga tidak harus setuju, tentu dengan cara yang sopan, tentang semua hal. Jadi setiap peserta dapat berbicara tentang hal-hal yang ada di dalam hatinya yang terdalam (Cheetham dkk. 2011, hal. 61).

Kegiatan SR memberi pelayanan keramahan kepada para penganut kepercayaan Ibrahamik karena diharapkan setiap partisipan memiliki hubungan saling menghormati dengan yang lainnya juga memberikan perhatian kepada teks kepercayaan umat lain. Kegiatan ini sangat cocok sebagai tempat untuk memelihara komunikasi. Bahkan tidak jarang pula setiap partisipan akan menemukan kesalahan asumsi-asumsi yang selama ini diyakininya terhadap umat kepercayaan lain meskipun terkadang itu membutuhkan waktu (Harrison, 2010, hal. 2).

\section{Langkah-Langkah SR}

Sebelum memulai SR, ada beberapa elemen yang perlu ada yaitu pertama, tempat. Peserta SR harus memiliki tempat untuk berdiskusi. Umumnya tempat yang dijadikan diskusi ialah tempat yang netral dari simbol-simbol agama. Kedua, supaya diskusi berjalan dengan nyaman diperlukan seperti meja melingkar supaya para peserta dapat saling menatap. Ketiga, dalam satu kelompok SR terdiri dari beberapa keyakinan, idealnya terdapat umat Islam, Kristen, dan Yahudi. Keempat, ada teks-teks kitab suci yang akan digunakan (Alkitab dan Alquran). Kelima, ada rentang waktu yang ditentukan supaya dialog dapat berjalan efektif dan efisien (Ochs \& Ziad, 2010, hal. 39; Lorie, 2013).

Setelah elemen-elemen terpenuhi, kegiatan SR dapat dilaksanakan. Adapun langkah-langkah SR yaitu, pertama sebelum melakukan SR, para peserta harus memutuskan tema apa yang akan dibahas (Ochs, 2012, hal. 17). Pemilihan tema dapat dilakukan di hari sebelumnya atau langsung di tempat. Misalnya penganut Kristen memilih teksnya sendiri, begitu pun 
dengan umat Islam dan Yahudi (Cheetham dkk. 2011, hal. 61-62).

Kedua, kelompok Scriptural Reasoning berjalan dengan sangat baik jika ada seseorang yang bersedia menjadi fasilitator. Idealnya, orang tersebut adalah orang yang telah melakukan SR cukup banyak. Dia bertanggung jawab untuk menjaga waktu dan dengan lembut menolong orang-orang mengikuti pedoman. Selanjutnya fasilitator membagikan draf (bundle) teks-teks dari kitab suci tetapi jika setiap peserta sudah memilikinya, maka hal itu tidak perlu dilakukan (McCallum, 2013, hal. 5; Ochs, 2012, hal. 17).

Ketiga, mulai membaca.

Kelompok SR memutuskan bersama teks yang mana yang akan dibacakan terlebih dahulu. Setiap orang memiliki salinan dari teks tersebut di depan mereka. Diperbolehkan ada satu dua orang yang berbicara tentang teks tersebut selama beberapa menit. Bukan untuk memberi intrepretasi melainkan seperti memberikan informasi tentang konteks surat ayat kirab tersebut (Lorie, 2013, Ochs, 2012, hal. 18).

Keempat,yaitu setiap peserta dapat langsung melakukan dialog bersama. Siapa yang kurang akrab dengan teks tersebut dapat bertanya untuk klarifikasi, atau menunjuk poin yang menarik bagi mereka. Setiap partisipan dianjurkan untuk berusaha menjawab tantangan-tantangan tersebut dari berbagai sumber pengetahuan. Tidak boleh ada jawaban yang menutup untuk didiskusikan. Bahkan jawabanjawaban mereka seringkali membangkitkan tantangan dan jawaban lain. Penganut kepercayaan yang kitab sucinya sedang dibahas, bukan menjadi guru yang otoriter, atau perwakilan resmi dari agamanya. Jika mereka ingin, mereka dapat berbagi tentang refleksi dari tafsiran tradisi mereka, dimana mereka akan membacakan satu atau dua teks sebelumnya dan dapat memberikan hikmah selama diskusi. Perdebatan atau diskusi berlangsung di tempat. Panduan atau arahan dilakukan oleh fasilitator menjadikan diskusi ini terus berlangsung dan tanpa kesimpulan sebab sejak awal tujuan umum dari kegiatan SR ini bukan untuk memberikan jawaban final terhadap kasus atau permasalahan yang ada. Penalaran itu sendirilah yang menjadi tujuannya (Ochs, 2012, hal. 17-18; Ochs \& Ziad, 2010, hal. 39, McCallum, 2013, hal. 5).

SR bukanlah proses yang mengajarkan cara yang 'benar' untuk membaca atau menafsirkan kitab suci tetapi lebih kepada kesempatan untuk mendengarkan kitab suci kepercayaan lain dan memahaminya. Tidak mengapa jika menemukan bahwa peserta lain tidak yakin atau tidak setuju atau memiliki pertanyaan, atau ketidaksamaan antara peserta yang berasal dari tradisi yang sama (McCallum, 2013, hal. 7).

Kelima, bergerak lebih dalam. Setelah beberapa saat, diskusi cenderung berubah. Daripada pertanyaan klarifikasi, peserta mulai mengusulkan bagaimana membuat teks masuk akal. Kegembiraan membaca dan memahami teks menunjukkan betapa hal tersebut penting, bukan hanya untuk pemiliki kitab sucinya tetapi juga untuk semua peserta kelompok. Setiap interpretasi 
menawarkan usul belaka. Hal itu tidak menggantikan atau mengancam kitab suci sebagaimana ditafsirkan oleh pemeluknya tetapi hal itu lebih sebagai refleksi langsung dari teks tersebut (Lorie, 2013).

Ada beberapa hal yang perlu diperhatikan dalam melakukan SR di antaranya pertama, tetap (terfokus) pada teks. SR akan sangat bermanfaat jika diskusinya fokus pada teks kitab suci yang ada di depan kita, dibandingkan diskusi umum tentang Kristen, atau Islam. Memang setiap peserta SR dapat memakai sumber lain selain pasal yang sedang dibahas tapi peserta harus selalu dapat menghubungkan apa yang ada di teks (Lorie, 2013).

Kedua, beri waktu kepada peserta lain untuk memberi tafsiran yang berbeda. setiap peserta mungkin memiliki ide yang jelas, tegas, dan sudah terbentuk dengan baik tentang bagaimana suatu teks kitab suci ditafsirkan, mungkin arti dari teks itu sudah sangat jelas atau ada peserta yang pernah mendengar pengajaran (penafsiran) tentang hal itu. Dalam SR, peserta tidak boleh memaksakan cara menafsirkan kepada peserta SR yang lain. Diskusi akan berhasil jika peserta lain mampu mengeksplorasi teks, termasuk tafsiran yang berbeda bagi mereka. Ini artinya, terkadang kita harus duduk tenang dan membiarkan diskusi untuk berjalan -yang anda pikir tafsirannya salah- lalu anda dapat menjelaskan dengan lembut bagaimana dan mengapa anda memiliki tafsiran yang berbeda (Lorie, 2013).

Ketiga, terbuka. Terbuka bukan berarti semberono atau sepele, atau menunjukkan rasa tidak hormat kepada kelompok atau kitab suci lain. Ochs dan kawan-kawannya telah menemukan bahwa diskusi akan berhasil jika peserta merasa bebas untuk menawarkan usulan bagaimana menafsirkan sebuah teks bahkan jika mereka adalah pendatang baru yang belum tahu apakah usulan mereka masuk akal atau tidak. Dan juga, ketika para peserta merasa bebas untuk bertanya, bahkan jika menurut mereka jawabannya mungkin sudah jelas bagi peserta yang lain (Lorie, 2013).

Keempat, jujur. peserta SR tidak harus orang-orang yang memiliki keilmuan agama yang mendalam. Siapa saja dapat melakukannya. Jadi jujurlah atas apa yang tidak diketahui atau tidak mengerti. Mungkin ada peserta yang tidak setuju dengan interpretasi yang lain dan tidak apa-apa untuk berkata demikian (lakukan dengan sopan) (Nelson, 2009, hal. 15).

Perencanaan Pembinaan Toleransi Beragama Melalui Metode Scriptural Reasoning

Berbicara mengenai perencanaan, idealnya dibutuhkan beberapa persiapan mulai dari menentukan tujuan, konten pembahasan, anggaran, media, metode, waktu, objek sasaran, hingga strategi evaluasi. Mengenai hal ini Bang Anjo dan Kang Ayi, dua orang koordinator nasional YIPC, menjelaskan bahwa sebenarnya di dalam komunitas YIPC sendiri, seluruh perencanaan interfaith dialogue SR ini sifatnya tidak terlalu formal, dan dapat dikatakan begitu simple.

Menurut Bang Anjo tujuan melakukan SR adalah diharapkan 
bahwa setiap peserta SR dalam YIPC dapat memiliki pemahaman yang berakar dari kitab suci, dapat mempelajari dan memahami nilai-nilai perdamaian langsung dari kitab suci, dan terlebih penting lagi adalah menerapkan apa yang telah dipelajarinya. Dalam melakukan SR pasti akan ditemukan perbedaan pendapat. Perbedaan ini berguna untuk memperkaya khazanah keilmuan dan juga rasa saling menghargai.

Adapun menurut Kang Ayi, kegiatan SR bertujuan untuk menjadikan anggota YIPC memiliki pengalaman yang baru, memiliki wawasan dan pemikiran dalam memahami suatu topik dari kitab suci yang berbeda-beda. Dari sana diharapkan tidak ada kesalahpahaman tentang orang lain, tentang kitab suci yang lain, dan tentang ajaran agama orang lain. Selain itu tujuan SR yang lain adalah supaya anggota YIPC dapat memperdalam ilmu agamanya masingmasing karena dalam pelaksanaannya secara umum umat agama lain akan bertanya mengenai maksud atau makna ayat Alquran.

Untuk bahan SR, menurut Bang Anjo, cukup mengadopsi bahan SR dari Universitas Cambridge, yang memang sudah memiliki pakar dan berpengalaman dalam pengembangan SR. Bahan ini disusun berdasar tematema tertentu yang bersifat tematis. Bahan SR ini dapat dijumpai di situs www.scripturalreasoning.org yang memuat 24 topik. Selain bahan dari Universitas Cambridge, YIPC juga menyusun bahan sendiri yang lebih bersifat kronologikal dari kisah para Nabi.
Mengenai perencanaan bahan ini, Kang Ayi mengatakan bahwa dia dan Bang Anjo, pertama-tama, merumuskan atau menyepakati dahulu topik-topik apa saja yang perlu dibahas dalam SR. Akhirnya mereka menyepakati topik kisah para Nabi. Selanjutnya Kang Ayi mencari ayatayat di dalam Alquran yang sesuai dengan topik Nabinya. Begitu pun dengan Bang Anjo, dia akan mengumpulkan ayat-ayat yang ada di dalam Alkitab, yang sesuai dengan topik.

Beralih kepada perencanaan anggaran. Menurut Bang Anjo, kegiatan interfaith dialogue SR ini tidak memerlukan anggaran sehingga tidak perlu bersusah payah untuk mencaricari dana. Cukup dengan membaca kitab-kitab suci (Taurat, Injil, dan Alquran) atau selembaran kertas yang berisi teks kitab-kitab suci, kegiatan SR dapat dilaksanakan. Berbeda dengan pernyataan Bang Anjo, Kang Ayi menyatakan bahwa kegiatan SR ini memerlukan anggaran, yaitu anggaran untuk media SR yang berupa kitabkitab suci (Alquran, Injil, Zabur, dan Taurat) atau draf foto copian yang berisi bahan SR. Hanya saja selama ini anggaran media sudah ditutupi oleh para donatur.

Perencanaan selanjutnya ialah media. YIPC juga merencanakan media yang diperlukan untuk kegiatan SR. Bang Anjo mengatakan bahwa ada dua media yang dipersiapkan ole YIPC, yaitu kitab-kitab suci dan draf SR.

Selanjutnya mengenai strategi atau langkah-langkah. Mengenai perencanaan langkah SR, YIPC sedikit banyak mengadopsi aturan main dari Universitas Cambridge. Ada empat 
langkah, pertama yaitu memilih teks yang akan didiskusikan. Teks adalah berasal dari Alkitab (taurat dan Injil) dan Alquran. Kedua, yaitu dengan memulai dengan membaca (bersama atau bergantian) teks kitab-kitab tersebut. Ketiga, memulai diskusi. Para peserta dapat meghabiskan waktu untuk mendiskusikan teks-teks tersebut. Keempat, bergerak lebih dalam.

Betapa pun, untuk mempermudah diskusi, YIPC telah mengembangkan beberapa format yang dapat dilaksanakan oleh para peserta SR dengan memberikan poinpoin pertanyaan praktis seperti apa yang dipelajari mengenai karakter Tuhan, Nabi, manusia, nilai perdamaian; ayat apa yang menarik perhatian atau menyentuh hati. Juga menyediakan sebuah pernyataan reflektif yang harus dinyatakan oleh para peserta SR seperti langkah praktis apa yang akan dilakukan setelah mempelajari teks tersebut; membagikan pengalaman pribadi yang berhubungan dengan pelajaran yang sedang dipelajari. Kemudian beralih ke perencanaan objek sasaran. Bang Anjo merencakan kegiatan SR kepada seluruh anggota YIPC. Adapun Kang Ayi menyatakan bahwa selain ditujukan kepada anggota YIPC, orang lain non-anggota YIPC yang tertarik kepada dialog SR pun diperbolehkan untuk mengikutinya.

YIPC juga merencakan waktu pelaksanaan SR. Sekurang-kurangnya SR akan dilaksanakan sebanyak dua kali saat kegiatan Training for Fasilitator, dan dua kali selama kegiatan Student Interfaith Peace Camp. Dalam perencanaan ini kegiatan SR tidak terlaksana secara tunggal atau menyendiri, melainkan merupakan satu dari serangkain kegiatan yang dilakukan oleh YIPC. Dalam perencanaan yang dibuat oleh YIPC, kegiatan Scriptural Reasoning dilaksanakan pada pukul 05.00-06.00 waktu setempat.

Terakhir mengenai perencanaan evaluasi. Saat diwawancara, Kang Ayi dan Bang Anjo menyatakan bahwa YIPC merencanakan evaluasi SR tetapi tidak terstruktur. Perencanaan evaluasinya yaitu mereka merencakan bahwa harus ada evaluasi yang dilakukan di setiap akhir event YIPC termasuk event National Conference dan Student Interfaith Peace Camp. Terakhir mengenai perencanaan evaluasi. Saat diwawancara, Kang Ayi dan Bang Anjo menyatakan bahwa YIPC merencanakan evaluasi SR tetapi tidak terstruktur. Perencanaan evaluasinya yaitu mereka merencakan bahwa harus ada evaluasi yang dilakukan di setiap akhir event YIPC termasuk event National Conference dan Student Interfaith Peace Camp.

\section{Proses Pelaksanaan Pembinaan Toleransi Beragama Melalui Metode Scriptural Reasoning}

Selama melakukan observasi, peneliti menemukan pola pelaksanaan yang secara umum sama, tidak terdapat perbedaan-perbedaan yang signifikan. Untuk itu di ruang yang terbatas ini peneliti cukupkan dengan memaparkan proses pelaksanaan SR yang dilaksanakan oleh YIPC di penginapan Green Gate, Cimbuleuit, Bandung yang diadakan pada tanggal 21 November 2015. Kegiatan SR ini 
dilaksanakan bukanlah bersifat tunggal atau menyendiri, melainkan merupakan satu dari serangkaian kegiatan YIPC yang disebut Student Interfaith Peace Camp.

Materi yang dibahas adalah mengenai Pertemuan dengan Tuhan (Encountering God) yang berasal dari kitab suci Taurat dan Alquran yakni dari Taurat adalah surat Keluaran 3: 18 dan dari Alquran adalah surat Thaha ayat 9-23. Media yang digunakan hanya berupa draf SR yang berisikan konten teks kitab suci. Adapun pesertanya ialah peneliti, Sasyka (Kristen) yang merupakan panitia kegiatan Peace Camp sekaligus sebagai fasilitator dalam kegiatan SR, Suri (Kristen), Azis (Muslim), Takwini (Muslim) yang merupakan mahasiswa UNPAD, Hendrik (Muslim) yang merupakan mahasiswa UPI, dan Yeni (Muslim) yang merupakan mahasiswa Universitas Advent Indonesia.

SR dimulai dengan doa bersama yang dipimpin oleh perwakilan agama, satu orang Muslim dan satu Kristen. Selanjutnya kami semua membagikan pengalaman menyenangkan yang pernah dialami. Setelah itu kami membahas teks. Pertama membaca teks Taurat, tetapi karena tidak ada yang bisa membaca teks bahasa aslinya (bahasa Ibrani) maka disingkat dengan langsung membaca tejemahannya. Adapun Alquran, dibacakan teks arab dan terjemahannya. Berjalannya SR seluruhnya dikendalikan oleh fasilitator.

Di sharing awal tiap peserta saling memberi tanggapan mengenai ayat yang sedang dibahas, mereka mengungkapkan karakter Tuhan dan Nabi Musa yang tercantum dalam
Taurat. Bagaimana Tuhan berbicara dengan Musa, bagaimana cara Nabi Musa menganggapi Tuhan, dan sebagainya.

Gambaran besar ayat ini menceritakan mengenai perjumpaan Musa untuk kali pertama dengan Allah. Peristiwa yang begitu agung dan begitu memengaruhi Musa yang membuatnya menjadi pemimpin besar Bani Israel dimana dia berusaha menyelamatkan umatnya dari kekejaman Fir'aun dan pasukannya. Musa memiliki rasa keadilan yang tinggi dan tiga kejadian dalam hidupnya mula-mula berkaitan dengan ketidakadilan. Dua kejadian pertama dialaminya ketika di Mesir, dan intervensi Musa yang kasar mengharuskannya untuk pergi dari Mesir. Kejadian ketiga, Musa membela sekelompok gadis dan akhirnya menikahi seorang dari mereka, Ziporah.

Suri menyatakan bahwa Allah memiliki rencana yang indah, Tuhan Maha Mengetahui, dan memiliki kasih sayang tinggi. Hal ini dibuktikan dengan pertolongan Tuhan kepada Musa dan umatnya yang sengsara di Mesir. Peserta yang lain mengungkapkan bahwa Tuhan memiliki karakter yang suci. Hal ini dapat dilihat bagaimana Musa harus melepaskan sepatunya. Setelah berdiskusi, para peserta SR diminta untuk mengungkapkan langkah konkret yang akan diperbuat. Selanjutnya, kegiatan diakhiri dengan membaca doa.

$\begin{array}{lr}\text { Hasil Pembinaan Toleransi } & \text { Tetode } \\ \text { Beragama Melalui } & \text { Metol Reasoing }\end{array}$


Keberhasilannya dapat dilihat dari hasil wawancara peneliti dengan Koordinator Nasional dan anggota YIPC. Hasil wawancara membuktikan bahwa kegiatan SR telah memberi hasil yang baik, salah satunya dengan adanya perubahan yang terjadi pada peserta SR.

Bang Anjo mengatakan bahwa hingga saat ini sudah ada perubahan yang terjadi dari para peserta SR, tetapi menurutnya masing-masing pribadi bisa berbeda-beda dampaknya, tergantung seberapa rajinnya mereka hadir dalam SR.

Senada dengan Bang Anjo, Kang Ayi mengatakan bahwa kegiatan SR ini telah berhasil. Mayoritas dari anggota YIPC, khususnya yang Muslim, menjadi lebih semangat untuk menggali sumber-sumber ajaran agamanya. Bagi muslim, bukan sekadar membaca Alquran tetapi juga menggali makna-maknanya. Selain itu, mereka juga mengetahui bahwa di setiap agama memiliki ciri khas ajarannya masing-masing dan setiap agama pasti titik temu dengan agama lain.

Apa yang dinyatakan oleh Bang Anjo dan Kang Ayi dapat diperkuat dengan hasil wawancara dengan beberapa anggota YIPC. Reza misalnya, salah satu anggota YIPC regional Bandung ini menyatakan bahwa ada perubahan di dalam dirinya terhadap pandangan dan wawasan Islam itu sendiri. Karena menurutnya saat proses diskusi berlangsung, dia tidak jarang mendapat ilmu yang baru dari hasil interpretasi teman Muslimnya, maupun dari hasil interpretasi teman Kristennya yang berusaha memahami ayat Alquran. Selain itu dia juga mengungkapkan bahwa telah terjadi perubahan pandangan terhadap agama lain. Dia jadi lebih terbuka, dan tidak berprasangka buruk lagi terhadap agama lain. Karena SR, dia pun mendapatkan wawasan terkait ajaran agama lain langsung dari sumbernya, bukan dari perkataan orang-orang Muslim yang terkadang salah memahami. Terakhir, dan ini yang menurutnya paling bermanfaat, yaitu kegiatan SR telah menguba sikapnya dalam menjalani kehidupan sehari-hari. Nilai-nilai yang digali di SR sedikit demi sedikit terimplementasi di dalam kehidupannya.

Diskusi Perencanaan Pembinaan Toleransi Beragama Melalui Metode Scriptural Reasoning

Peneliti menemukan bahwa komunitas YIPC telah membuat perencanaan SR mulai dari menentukan tujuan, bahan, strategi, anggaran, media, objek sasaran, waktu, hingga evaluasi.

Tujuan pembinaan toleransi beragama melalui kegiatan dialog SR ini memiliki untuk menanamkan nilainilai yang berakar dari kitab suci agamanya maupun agama lain, seperti nilai-nilai perdamaian dan toleransi sehingga mereka dapat mempraktikkannya dalam kehidupan sehari-hari. Materi yang diberikan merupakan bahan yang diadopsi Universitas Cambridge dan hasil buatan sendiri yang berkisar pada nilai-nilai universal. Strategi yang digunakan adalah strategi yang diadopsi dari penemunya, Peter Ochs, yang juga digunakan oleh Univeritas Cambridge. Anggarannya berasal dari dana donatur maupun anggota YIPC sendiri. Medianya 
adalah draf foto copian dan kitab-kitab suci (Taurat, Injil, Zabur, Alquran). Objek sasarannya adalah anggota YIPC dan non anggota YIPC. Adapun mengenai waktunya, terbagi menjadi dua tipe. Satu, merupakan waktu yang sudah direncakan secara mutlak dan baku, sedangkan satu lagi adalah waktu yang direncakan atas kesepakatan setiap anggota. Terakhir mengenai evaluasi adalah dilakukan secara tidak formal dengan lisan.

Jika dikaji secara mendalam, perencanaan yang dilakukan oleh YIPC ini memiliki kesesuaian dengan rumusan perencanaan menurut Syah (2007, hal. 2830) dan Suryosubroto (2002, hal. 27-35) yang diantaranya meliputi adanya tujuan yang hendak dicapai dari sesuatu yang direncakan; ada materi yang hendak disampaikan; adanya penetapan waktu kapan rencana tersebut akan dilaksanakan; ada sumber daya manusia yang akan melaksanakan rencana tersebut; pemilihan metode; penentuan media; serta penentuan strategi evaluasi.

Meskipun sudah cukup sesuai dengan rumusan perencanaan Syah dan Suryosubroto, namun terdapat beberapa kelemahan dalam rancangan yang dibuat oleh komunitas YIPC. Pertama, mengenai perencanaannya itu sendiri. Jika ditinjau dari segi waktu perencanaan, perencanaan SR yang dilakukan oleh komunitas YIPC masih belum ideal. Seharusnya dalam segi waktu, idealnya terdapat tiga buah perencanaan, yaitu perencanaan jangka pendek, jangka menengah, dan jangka panjang sebagaimana dinyatakan oleh Suryosubroto (2004, hal. 23). Perencanaan SR yang ada di YIPC masih merupakan perencanaan jangka panjang karena sifatnya yang masih umum dan fleksibel.
Adapun jika dilihat dari segi sifatnya, perencanaan yang dibuat oleh komunitas YIPC memiliki sifat perencanaan strategi dan operasional sekaligus, sebagaimana sifat perencanaan menurut Gunningham (dalam Pidarta, 2005, hal. 70) yang menyatakan bahwa dari segi sifatnya, perencanaan dapat digolongkan menjadi dua bagian, yaitu perencanaan strategis dan perencanaan operasional. Yang pertama lebih menekankan pada kebijakan yang diambil, pendekatan yang dipakai, kebutuhan yang diperlukan, misi, dan tujuan yang hendak dicapai, sedangkan perencanaan operasional lebih berkaitan dengan usaha-usaha praktis yang dipakai untuk mengaplikasikan perencanaan strategis.

Setelah menganalisis perencanannya, sekarang berlanjut ke setiap komponen perencanaan yang ada. Pertama mengenai perencanaan tujuan yang hendak dicapai. Terdapat kelemahan di dalam komponen perencanaan tujuan. Meskipun tujuan SR yang diutarakan oleh Bang Anjo dan Kang Ayi tidak berbenturan, bahkan saling menguatkan akan tetapi sayangnya tujuan tersebut tidak tercantum secara tertulis. Menurut peneliti hal ini cukup rawan sebab jika tujuan hanya tertera dalam ucapan, akan membuka celah-celah kealpaan/kesalahan persepsi. Dalam sebuah organisasi/ lembaga/komunitas pasti akan terjadi sebuah regenerasi. Jika tujuan SR tidak dituliskan secara baku, maka dimungkinkan akan terjadi penyelewengan di waktu yang akan datang yang dilakukan oleh generasi penerus, baik secara sengaja maupun tidak disengaja. Selain itu, dengan adanya penegasan tujuan, akan meminimalisir penyipangan yang mungkin terjadi di dalam pelaksanaan. Selain itu, ketidakjelasan tujuan, karena tidak tertulis 
secara baku, akan berdampak kepada seluruh rangkaian perencanaan lainnya, terutama pada perencanaan pelaksanaan dan perencanaan evaluasi.

Adapun keunggulan dari tujuan SR yang ada di komunitas YIPC, terlepas dari kekurangannya sebagaimana dipapakan di atas, adalah selaras dengan tujuan SR yang direncakan oleh penemunya, Peter Ochs, yakni menalar kitab suci adalah tujuannya itu sendiri (Ochs, 2012, hal. 18). Selain itu, tujuannya pun selaras dengan tujuan pendidikan nasional yang tertera dalam UU No.20 tahun 2003 yakni mencerdaskan kehidupan bangsa dan mengembangkan manusia Indonesia seutuhnya, yaitu manusia yang beriman dan bertakwa terhadap Tuhan Yang Maha Esa dan berbudi pekerti luhur, memiliki pengetahuan dan keterampilan, kesehatan jasmani dan rohani, kepribadian yang mantap dan mandiri, serta rasa tanggung jawab kemasyarakatan dan kebangsaan (MKDP, 2011, hal. 148-149), pun bersesuaian dengan visi YIPC, yakni menciptakan generasi damai yang berdasar atas kasih kepada Allah dan sesama; serta bersesuaian dengan nilai-nilai dasar YIPC, yakni berdamai dengan Allah, diri sendiri, sesama, dan berdampak kepada lingkungan.

Kedua, mengenai perencanaan bahan. Secara umum menurut Fathoni dan Riyana (MKDP, 2011, hal. 152) bahan dapat dikategorikan menjadi tiga butir unsur utama, yaitu memuat logika (pengetahuan benar-salah), etika (pengetahuan baik-buruk), dan estetika (pengetahuan mengenai indah-jelek). Jika dikaji, bahan yang direncanakan ole YIPC memuat ketiga unsur tersebut sekaligus. Bahan-bahan yang ada di YIPC seluruhnya berasal dari kitab suci yang mana isinya tentu memuat pengetahuan logika, etika, dan estetika.

Ketiga, mengenai perencanaan strategi. Menurut Fathoni dan Riyana (MKDP, 2011, hal. 153) terdapat enam butir faktor yang memengaruhi bentuk strategi dalam melakukan pembelajaran, yakni tujuan, materi, pelajar, fasilitas, waktu, dan pengajar. Jika dikaji, perencanaan strategi yang ada di dalam komunitas YIPC telah mempertimbangan faktor-faktor tersebut. Dengan mempertimbangkan tujuan SR, yaitu menanamkan nilai-nilai kita suci, strategi yang digunakan selalu diarahkan kepada pemusatan kitab suci. Dengan mempertimbangkan materi, yaitu hal-hal pokok yang ada di dalam kitab suci, strategi yang digunakan sesuai dengan materi yang disajikan. Dengan mempertimbangkan peserta SR (mahasiswa ke atas), strategi yang digunakan disesuaikan dengan pola pemikiran tingkat mahasiswa (diskusi mendalam). Dan dengan mempertimbangkan fasilitas, strategi yang digunakan dengan memaksimalkan fasilitas yang ada, serta dengan mempertimbangkan waktu, strategi yang digunakan telah disesuai dengan waktu para peserta SR.

Keempat, mengenai perencanaan media. Menurut Fathoni dan Riyana (MKDP, 2011, hal. 162) media pembelajaran digolongkan menjadi tiga buah golongan yaitu media visual, audio, dan audio-visual.

Media yang direncakan oleh komunitas YIPC setidaknya telah cukup memenuhi syarat tersebut, yaitu dengan menggunakan media visual, meskipun akan menjadi lebih baik lagi jika menggunakan media audio-visual. 
Proses Pelaksanaan Pembinaan Toleransi Beragama Melalui Metode Scriptural Reasoning

Menurut Saefullah (2009, hal. 98) terdapat tujuh prinsip yang seharusnya muncul di dalam sebuah pelaksanaan diantaranya, memperlakukan pegawai (peserta kegiatan) dengan baik, mendorong pertumbuhan dan perkembangan manusia, menanamkan kepada manusia keinginan untuk melebihi, menghargai hasil yang baik dan sempurna, mengusahakan adanya keadilan tanpa adanya pilih kasih, memberikan kesempatan yang tepat dan bantuan yang cukup, dan memberikan dorongan untuk mengembangkan potensi dirinya.

Dari hasil wawancara dan observasi, peneliti cukup melihat prinsip-prinsip pelaksanaan di atas. Dalam seluruh kegiatan SR, fasilitator memperlakukan para peserta SR dengan baik dan mendorong mengembangkan potensi dirinya. Hal ini dapat terlihat saat para fasilitator memberikan kesempatan kepada para peserta untuk membaca teks asli kitab suci. Saat observasi pelaksanaan SR pertama, peneliti mengamati bahwa Bang Anjo memberikan kesempatan kepada Carol untuk membaca teks asli Injil yang berbahasa Yunani. Begitu yang terjadi saat observasi pelaksanaan SR yang keempat dimana Bang Oswin, selaku fasilitator memberikan kesempatan kepada Agus untuk membacakan teks asli kitab suci Alquran. Kegiatan ini tentu mendorong mereka untuk dapat melancarkan bacaannya. Para fasilitator juga berlaku adil kepada seluruh peserta SR. Ini terlihat, satu contoh, saat Kak Saskya memberikan kesempatan kepada seluruh peserta untuk berbicara atau berargumen. Mengenai prinsip penanaman diri untuk melebihi juga tumbuh di salah satu anggota YIPC. Ela menyatakan bahwa sekarang dirinya memiliki kesadaran untuk memahami Alquran lebih dalam, tidak hanya dapat membacanya dalam bahasa arab, tetapi juga mencoba memahami dalam bahasa Indonesia (maknanya) juga.

Gafur (1978, hal. 7) menyatakan bahwa pembinaan ialah sebuah upaya pendidikan yang dilakukan secara sadar, terarah, teratur, dan bertanggung jawab dalam rangka membimbing dan mengembangkan kepribadian yang mandiri.

Berdasarkan penjelasan di atas, pelaksanaan pembinaan toleransi beragama melalui metode SR dalam komunitas YIPC telah dilakukan secara sadar, terarah, dan bertaggung jawab. Hasil observasi menunjukkan bahwa seluruh peserta SR sadar bahwa dirinya sedang melakukan kegiatan tersebut. Tidak ada satu orang peserta yang diikutsertakan secara paksaan maupun ketidaksadaran. Pada saat observasi SR kedua dan ketiga peneliti mengamati bahwa para peserta, yaitu Saskya, Suri, Azis, Takwini, Hendrik, Yeni, dan peneliti sendiri, benar-benar menyadari kalau kami sedang melakukan SR dan itu pun dilakukan atas dasar suka rela tanpa paksaan sehingga hasilnya pun dapat dipertanggung jawabkan.

Selanjutnya mengenai pendekatan pembinaan. Sudjana (2010, hal. 218-223) menyatakan bahwa terdapat dua jenis pendekatan dalam pembinaan, yaitu pendekatan langsung 
dan tidak langsung. Jika melihat kedua jenis pendekatan di atas, pelaksanaan pembinaan yang dilakukan oleh komunitas YIPC lebih besifat langsung. Dimana fasilitator dan seluruh peserta saling bertemu, dan bertatap muka langsung tanpa melalui perantara apapun karena di kegiatan ini merupakan sebuah kegiatan yang memelukan diskusi yang cukup mendalam.

Materi kajian pembinaan yang dilaksanakan oleh komunitas YIPC berdasarkan hasil observasi ialah, pertama adalah wanita dan kesetaraan (Yahya 8: 2-11 dan Ali Imran 35-43), kedua adalah pertemuan dengan Tuhan (Keluaran 3:1-8 dan Thoha: 923), ketiga adalah pendidikan agama (Ulangan 11: 16-21, 2 Timotius 3: 13 17, dan Al-Alaq 1-5).

Hasil penemuan penelitian yang dipaparkan di atas, cukup sesuai dengan teori materi yang hendaknya diberikan kepada manusia menurut Fathoni dan Riyana (MKDP, 2011, hal. 152) yakni bahan atau materi dapat dikategorikan menjadi tiga butir unsur utama, yaitu memuat logika (pengetahuan benar-salah), etika (pengetahuan baik-buruk), dan estetika (pengetahuan mengenai indah-jelek). Jika dikaji, materi yang dilaksanakan oleh YIPC memuat ketiga unsur tersebut sekaligus. Bahan-bahan yang ada di YIPC seluruhnya berasal dari kitab suci yang mana isinya tentu memuat pengetahuan logika, etika, dan estetika. Tidak sampai disana, bahanbahan yang dipakai oleh YIPC selaras dengan bahan yang dibuat atau digunakan oleh penemunya, Peter Ochs. Bahan ini dapat dilihat langsung didalam website resminya.
Hasil observasi menunjukkan bahwa dalam pelaksanaan Scriptural Reasoning pada komunitas Young Interfaith Peacemaker Community terdapat beberapa media yang digunakan seperti, draf yang berisi materi-materi SR; kitab-kitab suci diantaranya Taurat, Injil, dan Alquran; dan smartphone.

Jika dianalisis, media-media seperti draf dan kitab-kitab suci dapat digolongkan ke dalam media visual yang menurut Fathoni dan Riyana (MKDP, 2011, hal. 162) merupakan media yang hanya dapat diindra dengan menggunakan indra penglihatan. Media visual ini dapat dibagi menjadi dua bagian, yaitu media visual yang dapat diproyeksikan dan media visual yang tidak dapat diproyeksikan. Maksud media visual yang dapat di proyeksikan adalah media visual yang dapat menampilkan gambar diam maupun gambar yang bergerak. Jika di analisis, media-media yang digunakan oleh YIPC termasuk ke dalam kategori media visual non proyeksi, yaitu media cetak.

Jika dianalisis, berdasarkan hasil observasi, media yang digunakan oleh YIPC telah cukup memenuhi ketiga syarat simbol pesan visual di atas. Draf yang berisi kutipan ayat-ayat dari kitab suci dan kitab-kitab suci (Taurat, Injil, Alquran) begitu sederhana dan setidaknya umat beragama yang memiliki concern terhadap agamanya, sudah pasti dapat membacanya dengan mudah. Media draf pun memiliki penekanan pada teks kitab suci. Selanjutnya mengenai keterpaduan. Media-media yang digunakan oleh YIPC memiliki keterpaduan antara teks asli kitab suci yang menggunakan bahasa Ibrani, Yunani, dan Arab 
dengan bahasa terjemahannya (Indonesia, Inggris).

Jika ditelusuri, penggunaan media berupa draf ini pun sesuai dengan anjuran yang dihimbau oleh penemunya yang menyatakan bahwa setiap peserta SR harus memegang teks dari kitab-kitab tersebut (Lorie, 2013; McCallum, 2013, hal. 5; Ochs, 2012, hal. 17).

Selain itu dari pelaksanaan SR dengan menggunakan media-media tersebut telah sesuai dengan perencanaan yang dibuat oleh YIPC, sebagaimana yang dinyatakan oleh Kang Ayi bahwa media yang dapat digunakan oleh YIPC saat melakukan SR adalah berupa draf yang berisi teks kitab suci dan kitab-kitab suci, baik Taurat, Injil, maupun Alquran.

Dari hasil pengamatan peneliti, komunitas YIPC memiliki dua jenis waktu dalam pelaksanaan SR. Pertama, adalah waktu yang sudah ditentukan terlebih dahulu, dan kedua adalah waktu yang belum ditentukan sedari dulu, melainkan berdasarkan kesepakatan anggota YIPC.

Selanjutnya jika di analisis, waktu pelaksanaan SR yang dilakukan oleh YIPC masih sesuai dengan anjuran penemunya. Higton (Lorie, 2013) menyatakan bahwa pelaksanaan SR kadang menghabisan waktu yang singkat tetapi juga kadang dapat menghabiskan waktu yang cukup panjang. Dalam ketiga pengamatan awal pelaksanaan SR dapat digolongkan menjadi jenis waktu yang dilaksanakan secara singkat, sedangkan saat pelaksanaan SR yang keempat dan kelima dapat digolongkan menjadi jenis waktu yang pelaksanannya cukup panjang.
Jika dikaji, pelaksanaan dari segi objek sasaran yang dilakukan oleh komunitas YIPC telah sesuai dengan perencanannya, dimana peneliti mengamati bahwa terdapat orang diluar anggota YIPC yang juga mengikuti kegiatan SR. Agus, seorang mahasiswa yang bukan termasuk anggota komunitas YIPC bergabung untuk mengikuti kegiatan SR di rumah Bang Oswin.

Menurut Arifin (2014, hal. 24-25) terdapat tiga ruang lingkup evaluasi, yaitu program, proses pelaksanaan, dan hasil. Untuk program ada tujuh bagian yang harus dievaluasi yaitu tujuan pembelajaran secara umum; isi; metode; media; sumber belajar; lingkungan; penilaian proses dan hasil belajar, baik yang menggunakan tes maupun non-tes. Untuk proses pelaksanaan, terdapat tiga bagian yang harus dievaluasi adalah kegiatannya, guru, dan pendidik. Untuk lingkup hasil dievaluasi keberhasilannya menurut jangka waktunya.

Berdasarkan hasil pengamatan, saat pengurus YIPC melakukan evaluasi kegiatan Student Interfaith Peace Camp (SIPC) di Bandung, mereka tidak melakukan evaluasi terhadap kegiatan SR, melainkan mengevaluasi jumlah anggaran pengeluaran yang ternyata lebih besar dibandingkan estimasi.

Oleh karena itu dapat dikatakan bahwa anggota YIPC regional Bandung saat itu tidak melakukan evaluasi program, proses pelaksanaan, maupun hasil. Selai itu merea juga tidak melaksanakan perencanaan yang direncanakan suda direncanakan, sebab menurut Bang Anjo evaluasi SR harus dilakukan setidaknya satu kali di 
akhir kegiatan Student Interfaith Peace Camp (SIPC).

Akan tetapi berbeda halnya dengan pernyataan Kang Ayi. Saat diwawancara dia menyatakan bahwa sering melakukan evaluasi terhadap anggota YIPC, khususnya kepada anggota yang beragama Islam yang dilakukan di sela-sela event.

Jika dikaji, setidaknya Kang Ayi sudah melakukan sebagian evaluasi di ruang lingkup proses sebagaimana yang dinyatakan oleh Arifin (2014, hal. 25) yaitu evaluasi terhadap peserta didik (peserta SR). Evaluasi ini berkaitan dengan materi yang mereka pahami, perhatian mereka saat pelaksanaan SR, keativitan, motivasi, sikap, dan minat mereka terhadap kegiatan SR.

\section{Hasil Pembinaan Toleransi Beragama Melalui Metode Scriptural Reasoning}

Berdasarkan hasil wawancara, dapat disimpulkan bahwa tingkat keberhasilan diadakannya pembinaan toleransi beragama melalui metode SR di YIPC ini dapat dikatakan berhasil dengan hasil yang cukup memuaskan. Menurut mereka, setelah melakukan SR mereka menjadi lebih semangat untuk memperdalam ilmu agamanya masing-masing, mengetahui letak persamaan dan perbedaan antara kedua agama, wawansan keagamaan meningkat, pandangannya menjadi terbuka dan tidak berburuk sangka kepada orang yang berbeda agama, memiliki hubungan yang lebih dekat (menjalin pertemanan dan persahabatan) dengan yang berbeda berbeda agama, dapat melihat adanya kebenaran dalam kitab agama lain, dan yang paling tertinggi adalah dapat menerapkan isi kandungannya ke dalam kehidupan sehari-hari.

Adapun hasil observasi peneliti menunjukkan bahwa sikap Bang Oswin sepanjang peneliti berada di rumahnya, dia sangatlah baik. Menghormati tamu, dan memberikan pelayanan yang maksimal, meskipun kami berbeda agama. Dia juga tidak ragu untuk mengutarakan kebenaran yang terdapat dalam kitab suci Alquran, meskipu dia adalah seorang yang beragama Kristen.

Hasil ini setidaknya sudah cukup sesuai dengan tujuan yang hendak dicapai oleh komunitas YIPC, sebagaimana yang diungkapkan oleh Bang Anjo, yakni memiliki pemahaman yang mengakar pada kitab suci, dan menerapkan ajaran tersebut ke dalam perilaku sehari-hari (W.NC1). Selain itu, hasil ini pun sudah mengarah kepada visi komunitas YIPC, yaitu generasi damai yang berdasar atas kasih kepada Allah dan sesama.

Tidak sampai disana, hasil yang diperoleh pun sudah cukup selaras dengan tujuan kegiatan SR menurut penemunya, Peter Ochs, yakni kegiatan menalar kitab suci itu sendiri adalah tujuannya (Ochs, 2012, hal. 18) atau sebagaimana yang dijabarkan oleh Taylor (2008, hal. 5), "the the purpose of Scriptural reasoning is to learn about God's intentions for us and for the world and to bring about its repair. As such, it is a practice that nurtures the discipline of mutual hospitality."

Adapun jika dikaji secara mendalam, akan ditemukan bahwa hasil yang diperoleh dalam pembinaan 
toleransi beragama ini adalah menghasilkan manusia-manusia beragama yang memiliki sikap toleran versi Alquran sebagaimana dicirikan oleh Suryana (1997, hal. 185-186), yakni tidak melakukan pemaksaan untuk masuk ke dalam agama Islam baik secara kasar maupun halus, memberikan kebebasan untuk memilih agama yang diyakininya, dan berinteraksi dengan yang berbeda agama dengan baik.

\section{KESIMPULAN}

Berdasarkan hasil penelitian yang dilakukan pada komunitas Young Interfaith Peacemaker Community, yang telah dianalisis dengan menggunakan teori-teori yang relevan, maka kesimpulan yang dapa diambil dalam penelitian ini sebabagai berikut:

1. Perencanaan pembinaan toleransi beragama melalui metode SR pada komunitas YIPC penentuan tujuan, bahan/materi, strategi (langkahlangkah), anggaran, media, objek sasaran, waktu, hingga evaluasi. Betapa pun, ada beberapa kelemahan seperti tidak adanya penentuan tujuan secara tertulis (baku) dan tidak adanya perencanaan teknik evaluasi yang terstruktur.

2. Proses pelaksanaan toleransi beragama melalui metode SR pada komunitas YIPC secara umum telah berjalan dengan baik dan sesuai dengan perencanaan yang telah dipaparkan. Hanya saja ada beberapa bentuk pengembangan atau variasi dalam proses pelaksanaannya seperti adanya tahap awal (kegiatan pembukaan) berupa doa pembuka dan sharing pengalaman; dan tahap akhir (kegiatan penutup) berupa doa penutup, dimana kedua tahap ini tidak terdapat di dalam perencanaan.

3. Mengenai hasil pembinaan toleransi beragama melalui metode SR pada komunitas YIPC ini secara umum dapat dikatakan berhasil. Secara umum peserta SR mengalami perubahan yang positif setelah melakukan SR. Mereka lebih semangat untuk menggali ilmu yang terdapat di dalam tradisi agamanya masing-masing, menjadi tahu dan menghargai adanya perbedaan yang khas di setiap agama tetapi mereka juga menemukan adanya sebuah titik temu. Selain itu mereka akhirnya memiliki pemikiran yang terbuka dan tidak berprasangka buruk terhadap tradisi agama lain. Mereka juga dapat menjalin pertemanan atau persahabatan dengan yang berbeda agama, dan yang paling utama yaitu kegiatan SR telah mengubah pola kehidupan mereka, menjadi orang yang lebih berusaha menjalankan perintah-perintah Tuhan. Adapun ukuran keberhasilannya dapat dilihat dari tujuan SR dan visi misi komunitas YIPC, selain itu juga diukur dari tujuan SR menurut penemunya. 


\section{DAFTAR PUSTAKA}

Arifin, Z. (2014). Evaluasi Pembelajaran. Bandung: Rosda.

Cheetham, D., Valkenberg, P., Rettenbacher, S., Slakter, D., Adams, N., Egnell, H., et al. (2011). Interreligious hermeneutics in pluralistic europe: between texts and people. Newyork: Kodopi.

Gafur, A. (1978). Pola Dasar Pembinaan dan Pengembangan Generasi Muda. Jakarta: Sekertariat Menteri Muda Urusan Pemuda Departemen Pendidikan dan Kebudayaan.

Geddes, J. L. (2004, Spring). Peacemaking among the abrahamic faiths: an interview with Peter Ochs. Hedgehog Riview, 6(Issue 1), 90-102.

Harrison, S. K. (2010, Agustus 5). Jews, christians and muslims reading scriptural together. Retrieved Januari 2, 2016, from

www.commongroundnews.org: www.commongroundnews.org/arti cle.php? $\mathrm{id}=28226 \& \operatorname{Ian}=\mathrm{en} \& \mathrm{sp}=0$

Kepnes, S. (2006). A handbook for scriptural reasoning. Modern Theology, 22(Issue.3), 367-383.

Lorie. M. (2013). Scriptural Reasoning: $A$ How to Guide. Diperoleh dari https://www.youtube.com/wat ch?v=rjNIcagkVC

LSI. (2019). Tantangan Intoleransi dan Kebebasan Sipil serta Modal Kerja pada Periode Kedua Pemerintahan Joko Widodo. Diakses 9 Mei 2020 pada

www.lsi.or.id/riset/447/rilissurvei-lsi-03-november-2019

McCallum, R. (2013, November 1). Evaluation of the cambridge programme summer school. Retrieved Januari 29, 2016, from Academia Web Site: https://www.academia.edu/19516 572/Evaluation_of_the_Cambridg e_Programme_Summer_School

MKDP, T. P. (2011). Kurikulum \& Pembelajaran. Jakarta: Rajawali Pers.

Nelson, R. D. (2009). Gideon and Baal: a test case for interfaith dialogue. Journal of Inter-Religious Studies, 1519.

Ochs, P. (2012). An introduction to scriptural reasoning: from practice to theory. Journal of Renmin University of China, 26, 16-22,.

Ochs, P., \& Ziad, H. (2010). Grassroots scriptural reasoning on Campus. Journal of Inter-Religious Dialogue, 3845.

Pidarta, M. (2005). Perencanaan Pendidikan Parsipatori dengan Pendekatan Sistem. Jakarta: Rineka Cipta.

PPIM. (2017). Api dalam Sekam: Keberagamaan Muslim Gen-Z. Survei Nasional tentang Keberagamaan di Sekolah dan Universitas di Indonesia. Diakses 9 Mei $2020 \quad$ pada www.ppim.uinjkt.ac.id/publikasi /infographic-factsheet/

Saefullah, K. (2009). Pengantar Manajemen. Jakarta: Salemba Empat.

Su'aidi, H. (2012, Oktober). Kekerasan atas nama agama vis a vis amar makruf nahi munkar. Refleksi: Jurnal Ilmu-Ilmu Ushuluddin, 13, 305-324.

Sudjana, D. (2010). Manajemen Program Pendidikan. Bandung: PT Remaja Rosdakarya.

Suryosubroto, B. (2002). Proses belajar mengajar di Sekolah. Jakarta: Rineka Cipta.

Suryosubroto. (2004). Manajemen Pendidikan di Sekolah. Jakarta: Rineka Cipta. 
Syah, D. (2007). Perencanaan Sistem Pengajaran Pendidikan Agama Islam. Jakarta: Gaung Persada Press.

Tontowi, Y., Firdaus, A., Khaliluddin, T., Ghazali, D. A., \& Rais, M. (2010). Laporan kebebasan beragama/berkeyakinan dan toleransi 2010. Jakarta: The Wahid Institute. 